\title{
A Study of English Listening Comprehension Improvement via Product- vs. Process-Oriented Tactics: The Case Study of Shiraz EFL Learners
}

\author{
*Hamed Azizinia ${ }^{1}$, Hossein Sadeghoghli², Vahed Mohebkhah ${ }^{3}$ \\ 1. Young Researchers and Elite Club, Yasooj Branch, Islamic Azad University, Yasooj, Iran \\ 2 . Department of English Language Teaching, Sarab Branch, Islamic Azad University, Sarab, Iran \\ 3. Department of English Language Teaching, Nagadeh Branch, Islamic Azad University, Nagadeh, Iran \\ E-mail: Azizinia.hamed@gmail.com
}

Received: May 4, 2017 Accepted: July 17, $2017 \quad$ Online Published: September 20, 2017

\begin{abstract}
As listening comprehension plays an indispensable role in language learning, the way in which language instructors cover teaching listening comprehension has been controversial; the recent study selected two approaches to associate listening comprehension tactics: product-oriented and process-oriented. A quasi-experimental design was adopted to get to the objectives. Using a random procedure, 120 male students ranging in age from 15 to 18 were selected and were randomly allocated to two experimental and control groups. Subsequently, a pre-test was given to both groups to approve that both groups began on equal traction, which was the case. The students were taught for 12 sessions, adopting a process-oriented approach for the experimental group and a product-oriented approach for the control group. The evaluation of the two groups in terms of their overall performance on listening comprehension indicated that the performance of the students receiving training in process-oriented approach to listening comprehension compensated the control group trained through product-oriented approach, which suggests a clear advantage of the former. The findings have implications for the ways in which listening comprehension, in general, are taught in language classes.
\end{abstract}

Keywords: listening comprehension, process-oriented approach, product-oriented approach

\section{Introduction}

Research into listening comprehension skill in first language is just a few decades old and only a small research presently exists in second language listening literature. There is hardly sound research in this area, mainly due to the claim made that mostly the educational systems are reading-oriented and listening is a rather smooth concept which may not lead to concrete results; among other things, the reason being given is that in listening we are dealing with the interactions of the mind and the mind is not readily available or observable for objective analysis (Scanlon, 2005).

Teaching listening in comparison with the past is more interesting these days. In recent years, listening has not merely been used for comprehension but also it has been reflected as a means of language teaching (Richards, 2003). In order to show the importance of listening, Pourhosein Gilakjani and Ahmadi (2011) pointed out that for understanding a text at higher level, it is critical to comprehend the input. So, listening is a fundamental skill. Richards (2003) holds that, "Listening as comprehension is the traditional way of thinking about the nature of listening" (p.3). According to him, listening as acquisition is based on the following assumptions: Listening serves the goal of extracting meaning from messages.

- Learners have to be taught how to use both bottom-up and top-down processes to understand messages.

- The language of terms - the precise words, syntax, and expressions - used by speakers are temporary carriers of meaning.

- Teaching listening strategies can help learners to be more effective listeners.

In terms of distinguishing between product-oriented and process-oriented approaches, Onaka (2013) holds that in process-oriented approach to listening, the focus is on wrong answers. So, they use this as a clue for teachers to show 


\section{International Journal of Research in English Education}

them where the problem is and which part should be considered as the significant part in teaching while teachers do not pay attention to this. Pourhosein Gilakjani and Ahmadi (2011) believe that it is needed to change product-oriented listening classes to process-oriented ones. So, these classes can shift from teacher-centeredness to studentcenteredness which helps language learners to learn how to learn.

\subsection{Statement of the Problem}

In listening classes, language teachers and learners spend lots of time on listening activities, but they don't usually gain perceptible results. Really, in some cases, it is a waste of time. Another problem facing English learners is that they are exposed to a single type of listening approach in the listening classes. To tell the truth, in most English classes, educators hang on to the result of listening comprehension. They ask their students to answer listening questions correctly without considering the process of listening comprehension (Goh, 2000).

Teachers just notice the outcome of this skill. Actually, most of the time, teachers are testing their students not teaching them. Listening comprehension does not mean answering the questions correctly; sometimes learners comprehend the listening task completely but they can't answer the questions correctly (Seyyedi, 2017). Most EFL learners in Shiraz (Fars Province, Iran) fail to master listening and they are not autonomous in the process of listening comprehension. Given the discussion above, it could be said that the proper development of listening skill is a real problem in language classes and teachers and students always challenge with this experiment.

\subsection{Research Questions}

This study is guided by the following research questions.

1. Is there any significant difference between product-oriented approach and process-oriented approach to listening comprehension of EFL students?

2. Is there a specific aspect of listening comprehension which is best promoted through process-oriented or productoriented approach?

\section{Review of Related Literature}

According to Nunan (1995), listening is regarded as an important skill in both EFL classrooms and SLA research. Listening involves an active process of decoding and constructing meaning from verbal and non-verbal messages. Pourhosein Gilakjani and Ahmadi (2011) hold that listening is a hard work and it needs more mental analysis activity for the students because it is a passive activity, but it is a complex and active process in which the listener should understand the sounds and realize vocabulary, grammatical instruction, and stress and intonation of a text. So, it is necessary for the listener to do a number of things at the same time.

Listening plays an important role in communication; listening takes up 40-50\%; speaking, 25-30\%; reading, 11-16\%; and writing, about $9 \%$ of the total time in communication (Lynch, 2012). He holds that teaching of listening comprehension has long been somewhat neglected and a poorly taught aspect of English in many EFL programs; it is now regarded as much more important in both EFL classrooms and second language acquisition research.

Listening is assumed to bring about the same cognitive operations in either first language (L1) and second language (L2) or foreign language (FL). However, both efficiency of processing and cognitive affect differ in L1 and L2 listening but the main paradigms for the description and examination of L2 listening are derived from L1 psycholinguistics, including the development of L1 competence with spoken language (Hoven, 1999).

$\mathrm{Hu}$ (2002) counts the reasons that people cannot listen well. The emphasis in school was almost entirely on how to be an effective speaker. Listeners were viewed as objects; speakers were thought to analyze audiences as if they were scientists examining chemical components. Since no one was sure what is mean to improve your listening ability, they did not know exactly where to begin. Perhaps one reason why many people never learned to listen is that listening takes time. Language teachers and students tend to overlook listening prerequisite importance in language learning because there is no immediate observable output.

Lynch (2012) defines listening comprehension as the ability to understand the native speakers' spoken language. He also points out that, in listening to spoken language, the ability to decode the speaker's intention is of required for a competent listener, in addition to other abilities such as processing the linguistic forms like speech speed and fillers, 


\section{International Journal of Research in English Education}

coping with listening in an interaction, understanding the whole message contained in the discourse, comprehending the message without understanding every word, and recognizing different genres.

In the processes of comprehension after receiving the information, the hearer assigns a literal meaning to the utterance first and then assigns an intended meaning to the utterance as well. A key to human communication is the ability to match perceived meaning with intended meaning (Hu, 2002). Based on Lynch's (2012) research, active listening involves much more than just recognizing what is being said and comprehension is multi-layered, requiring interpretation at different levels. When we listen in our own language, we go beyond the input in all sorts of ways.

Nunan (1995) stated that a logical place to start in our investigation of listening is to consider the different purposes for listening and attempt to come up with a taxonomy of texts and consider the way in which they might be grouped together. It is also important and necessary to recognize the different purposes that listeners may have in different situations and how these differences in purposes affect the way they go on in listening.

Pourhosein Gilakjani and Ahmadi (2011) consider listening as highly-complex solving activities in which listeners interact with a speaker to construct meaning within the context of their experiences and knowledge. Teachers can engage students in activities that prepare them to be effective listeners by informing them about the efficient factors in listening, their levels of listening, and the listening process component.

Schemata theory sheds light on the importance of pre-listening activities. It includes outlines for listening and teaching the most essential conceptions. The two purposes of pre-listening activities which the teachers should pay attention to include: (a) to help to activate students' prior knowledge, to build up their expectations for the coming information, and (b) to provide the necessary context for the specific listening task. Teachers can use listening comprehension activities, like mutual daily life conversations; teachers can ask questions which require students' pervious knowledge activation. Controlled practice activity can also be used such as working on models with the same structure or vocabulary. Well-planned post-listening activities help students to connect what they have heard to their own ideas and experiences. Listening teachers can assign different comprehension questions for students to discuss after listening; students then switch information to complete the whole class chart, correlating what each student has heard to arrive at the big picture. In this phase of listening activity, the unanswered questions of previous listening activities can be worked on again and the whole class can listen to the tape again (Rubin, 1994).

\section{Methodology}

\subsection{Research Design}

The current study was experimental in design. The sampling procedure is cluster sampling, in which randomization is not feasible in all stages of choosing the participants. This study is quasi-experimental in design and involved a pretest post-test design.

\subsection{Participants}

The population of the study was English language learners in private language institutes in Shiraz. Out of these language institutes, two language institutes named Pars and Nategh were selected randomly and then two classes of intermediate level were chosen. For the purposes of this study, among these classes, 120 male participants out of 166 intermediate students were chosen as a sample of the study and randomly divided into experimental and control groups.

\subsection{Sampling Procedure}

The major consideration in the selection of participants was to choose a representative sample of population. The sampling method applied in this study was cluster sampling, which is a sampling technique where the entire population is divided into groups or clusters and a random sample of these clusters. All observations in the selected clusters are included in the sample. This sampling technique may well be more practical and economical than simple random sampling or stratified sampling (Kothari, 2004).

All the subjects had learned English in educational settings, meaning that they only had opportunity to use English and also listen to it in the classroom context. All the subjects were native speakers of Persian and had learned English as a foreign language. The total number of the students in the intended level was 166 learners who were studying TopNotch Series 2A. Among them, 134 students were selected based on their scores of the listening proficiency test to 


\section{International Journal of Research in English Education}

ensure that they qualified for the present study. The highest possible score was 20. Among 134 students who passed the proficiency test, 120 students were selected randomly. Thus, regarding the applied criteria, the participants were homogenous concerning their listening comprehension knowledge. Once the participants had been chosen, they were randomly assigned to two experimental and control groups. The participants' age ranged from 15 to 18 . Furthermore, to prevent the effect of gender difference on the results of the study, this variable was held constant among all participants and all the subjects were selected among male students.

\subsection{Instruments}

The instruments were two tests: a proficiency test, and a test for measuring listening comprehension of listeners. The test of listening comprehension was used for both pre-test and post-tests purposes. A proficiency test taken from the book titled Developing Tactics for Listening, third edition written by Jack. C. Richards (2003), Unit One, Listening two, was administered to the participants. This test contains a listening sub-test in true-false format (5 items) and a multiple choice listening sub-test (5 items).

Listening three in the book Developing Tactics for Listening was administered as both pre-test and post-test. The intention behind the pre-test was to ensure that the difference between the control and the experimental group was not significant in advance. The post-test was also administered to see whether the taken approach to teaching listening comprehension has an impact on the outcome of listening comprehension. The test comprised 10 items, consisting of three multiple-choice items and seven true-false items.

\section{Data Collection}

The proficiency test was administered to determine the students' level of proficiency and eliminate those who were not intermediate. First, all the 166 students who believed to be at the intermediate level were given a proficiency test. Based on the results of the test, 46 students were left out, as they did not score the minimum required. Out of the remaining test-takers, 120 students were randomly chosen as the participants of the study.

Following the assignment of participants to the control and the experimental groups, the participants were given a pretest of listening comprehension. Following the treatment, again they were given a post-test of listening comprehension.

The second phase of the study can be considered as the heart of the research since it was during this phase the experimental group undertook the treatment. The control group received a placebo, which was the instruction in the product-oriented approach to listening comprehension. The experimental group, however, received instruction in the process-oriented approach to listening comprehension. The pre-test and post-test were concerned with the first question of the study, which was about investigating the possible difference between product-oriented approach and process-oriented approach to listening comprehension. It is necessary to point out that the pre-test and the post-test were the same.

\section{Data Analysis}

In order to analyze the data, in addition to descriptive statistics, a series of independent-sample t-test was run to compare the two groups in terms of their performance on the pre-test of listening comprehension and the post-test. The pre-test was run to ensure that the difference between the groups in question in terms of listening comprehension was not significant prior to the study. Likewise, the post-test of listening comprehension was administered to determine the possible difference between the two approaches in terms of their impact on listening comprehension via respective t-test.

\section{Results}

\subsection{Pre-test}

The first comparison was made between the two groups in terms of their performance on the pre-test. In this case, no attempt was made to distinguish the sub-skills of listening. Rather, overall performance on listening comprehension was of interest. The results appear in the following two tables. 


\section{International Journal of Research in English Education}

Table 1. Frequency distribution of students' performance on the pre-test in terms of their listening comprehension skill

\begin{tabular}{|c|c|c|c|c|c|}
\hline \multicolumn{3}{|c|}{ Listening Comprehension of Control Group } & \multicolumn{3}{|c|}{$\begin{array}{l}\text { Listening Comprehensio } \\
\text { Experimental Group }\end{array}$} \\
\hline Scores & Frequency & Percent & Scores & Frequency & Percent \\
\hline 4 & 6 & 10 & 3 & 4 & 6.7 \\
\hline 5 & 16 & 26.7 & 4 & 6 & 10 \\
\hline 6 & 14 & 23.3 & 5 & 8 & 13.3 \\
\hline 7 & 18 & 30 & 6 & 20 & 33.3 \\
\hline 8 & 4 & 6.7 & 7 & 12 & 20 \\
\hline \multirow[t]{2}{*}{9} & 2 & 3.3 & 8 & 8 & 13.3 \\
\hline & & & 9 & 2 & 3.3 \\
\hline Total & 60 & 100 & Total & 60 & 100 \\
\hline Real Mean & 10 & & Real Mean & 10 & \\
\hline Std. Deviation & 1.26 & & $\begin{array}{l}\text { Std. } \\
\text { Deviation }\end{array}$ & 1.50 & \\
\hline
\end{tabular}

The data in the table above was used to work out the descriptive statistics of the performance of the two groups on the pre-test, as in the following table.

Table 2. Descriptive statistics of students' performance on the pre-test in terms of their listening comprehension skill

\begin{tabular}{|c|c|c|c|c|c|c|c|}
\hline \multirow[b]{2}{*}{ Variable } & \multirow[b]{2}{*}{ Group } & \multirow[b]{2}{*}{ Real mean } & \multirow{2}{*}{$\begin{array}{l}\text { The Students' } \\
\text { Mean Scores on } \\
\text { Listening } \\
\text { Comprehension }\end{array}$} & \multicolumn{2}{|c|}{ The lowest Score } & \multicolumn{2}{|c|}{ The highest Score } \\
\hline & & & & Real & Subjects & Real & Subjects \\
\hline \multirow{2}{*}{$\begin{array}{l}\text { Listening } \\
\text { Comprehension }\end{array}$} & Control & 10 & 6.07 & 0 & 4 & 10 & 9 \\
\hline & Experiment & 10 & 6.03 & 0 & 3 & 10 & 9 \\
\hline
\end{tabular}

Based on the table above and specifically given the means scores of 6.07 and 6.03 , it could be seen that there was no major difference between the control and the experimental groups in terms of their performance on the pre-test. It was also necessary to run an independent sample t-test to determine whether the minor difference between the two groups is statistically significant or not. The result appears below.

Table 3. Inferential statistics of the two groups' performance on listening comprehension of pre-test

\begin{tabular}{|c|c|c|c|c|c|c|c|}
\hline $\begin{array}{l}\text { Test } \\
\text { (Independent- } \\
\text { Sample t-test) }\end{array}$ & Group & $\mathrm{N}$ & $\begin{array}{l}\text { Listening } \\
\text { Comprehension } \\
\text { Mean }\end{array}$ & $\begin{array}{l}\text { Std. } \\
\text { Deviation }\end{array}$ & $\mathrm{T}$ & $\mathrm{Df}$ & Sig \\
\hline \multirow{2}{*}{ Pre-test } & Control & 60 & 6.07 & 1.26 & \multirow{2}{*}{0.093} & \multirow{2}{*}{58} & \multirow{2}{*}{0.926} \\
\hline & Experimental & 60 & 6.03 & 1.50 & & & \\
\hline
\end{tabular}




\section{International Journal of Research in English Education}

The table above clearly indicates that the difference between the two groups in terms of their overall performance on the pre-test of listening comprehension is not significant.

\subsection{Post-test}

Having determined that there was no significant difference between the two groups in terms of their overall performance on the pre-test, the researchers began the treatment. The experimental group received instruction in listening comprehension through process-oriented approach and the control group received instruction in the productoriented approach. After the treatment, a post-test of listening comprehension was administered to both groups.

\subsection{Descriptive Statistics}

Regarding the nature of the research questions raised in the study, just like the pre-test, it was necessary to do two comparisons between the experimental and the control groups in terms of their performance on the post-test. The first comparison was made between the two groups in terms of their overall performance on the post-test. Rather, overall performance on listening comprehension was of interest. The results appear in the following table.

Table 4. Descriptive statistics of students' performance on the post-test regarding overall listening comprehension skill

\begin{tabular}{|c|c|c|c|c|c|}
\hline \multicolumn{3}{|c|}{ Listening Comprehension of Control Group } & \multicolumn{3}{|c|}{ Listening Comprehension of Experimental Group } \\
\hline Scores & Frequency & Percent & Scores & Frequency & Percent \\
\hline 4 & 2 & 3.3 & 7 & 12 & 20 \\
\hline 6 & 22 & 36.7 & 8 & 18 & 30 \\
\hline 7 & 22 & 36.7 & 9 & 12 & 20 \\
\hline 8 & 10 & 16.7 & 10 & 18 & 30 \\
\hline 9 & 4 & 6.7 & & & \\
\hline Total & 60 & 100 & Total & 60 & 100 \\
\hline Real Mean & 10 & & Real Mean & 10 & \\
\hline Std. Deviation & 1.05 & & Std. Deviation & 1.13 & \\
\hline
\end{tabular}

\subsection{Inferential Statistics}

It was also necessary to run an independent sample t-test to determine whether the difference between the two groups is statistically significant or not. The results appear below.

Table 5. Inferential statistics comparing the performance of the two groups on the post-test

\begin{tabular}{|c|c|c|c|c|c|c|c|}
\hline Variable & Group & $\mathrm{N}$ & $\begin{array}{l}\text { Listening } \\
\text { Comprehension } \\
\text { Mean }\end{array}$ & $\begin{array}{r}\text { Std. } \\
\text { Deviation }\end{array}$ & $\mathrm{T}$ & D f & Sig \\
\hline Listening & Control & 60 & 6.83 & 1.05 & \multirow{2}{*}{6.26} & \multirow{2}{*}{58} & \multirow{2}{*}{0.000} \\
\hline Comprehension & Experimental & 60 & 8.60 & 1.13 & & & \\
\hline
\end{tabular}




\section{International Journal of Research in English Education}

The table above clearly indicates that the difference between the two groups in terms of their overall performance on the post-test is significant. Considering the mean score of the experimental group higher than that of the control group, therefore, the first question of the study is answered positively. Specifically, it could be seen that instruction through process-oriented approach is effective in enhancing the listening comprehension ability of the students.

\section{Discussion}

Pourhosein Gilakjani and Ahmadi (2011) held that listening is a passive activity but a complex and active process in which the listener should understand the sounds and realize vocabulary, grammatical instruction, and stress and intonation of a text. So, listening comprehension involves doing a number of things at the same time. Therefore, listeners require systematic training in listening comprehension to be able to make a good job of listening. According to Richards (2003), listening as comprehension is the traditional way of thinking about the nature of listening and as acquisition it is based on the following assumptions:

Listening serves the goal of extracting meaning from messages.

To do this, learners have to be taught how to use both bottom-up and top-down processes to understand messages.

The language of utterances-the precise words, syntax, and expressions-used by speakers are temporary carriers of meaning. Once meaning is identified, there is no further need to attend to the form of messages unless problems in understanding occurred.

Teaching listening strategies can help make learners more effective listeners.

As Chamot (2004) stated, to develop the students' auditory memory, the teacher should help the students hear as much as language as possible. In the last step, the listener processes what the speaker has said to comprehend the meaning. Thus far, all the above steps make comprehension possible but do not guarantee that understanding will occur. The initial step in comprehending language is to establish the context. Real language always occurs within a communicative framework. The next related step is to activate relevant background knowledge in order to get the message. In this study, an attempt was made to see whether instruction in listening comprehension received through process-oriented approach is more effective than instruction in the product-oriented approach. The students in the former group outclassed the students in the latter group. Having answered the research questions, we turn our attention to examining the findings of the study in the broader context of the relevant findings.

The first finding of the study is clearly in line with the findings so far. In similar studies carried out up to now, it has been the case that instruction through process-oriented approach is effective. To begin with, Richards (2003) stated that in process-oriented approaches, the focus is on the progress and development of a desirable process while in product-oriented approaches, the emphasis is on achieving a desirable outcome. It could be said that for language learners, product-oriented approach is rehearsing others' ideas while in process-oriented approaches, the students use their own strategies to learn.

Farrokhi and Modarres (2012) held that in process-oriented approach to listening, the spotlight is on wrong answers. So, they use this as a sign for teachers to show them where the problem is and which part should be regarded as an important part in teaching while in teaching listening as a product, teachers do not take this into account. Pourhosein Gilakjani and Ahmadi (2011) stated that it is necessary for teachers to change listening classes from product-oriented to process-oriented approach. So, these classes can change from teacher-centeredness to student-centeredness and language learners can learn how to learn. If process-oriented classes are more successful, language teachers and learners can decide to spend more time on listening as a process.

Feyten (1991) found that process-oriented approach is more attractive for instructors to deal with a large number of self-directed students in classroom. In listening comprehension classes, the focus is on addressing the problems of listening comprehension, not on the listening itself. In these classes, the emphasis is on product not process. It could be seen that the findings of the present study are clearly in line with the studies which have revealed that processoriented approach better enhances the students' listening skill. The present study also revealed that listeners use significantly more process-oriented strategies (i.e. guessing the meaning from the context and using the main idea to guess the meaning of the new words) than product-oriented approach. 


\section{International Journal of Research in English Education}

\section{Conclusion}

In this study, it was revealed that instruction in listening comprehension received through process-oriented approach is more effective than instruction in the product-oriented approach. The findings of a study carried out by Richards (2003) showed that earlier views of listening showed it as the mastery of discrete skills or micro skills, such as recognizing reduced forms of words, recognizing cohesive devices in texts, and identifying key words in a text, and that these skills should form the focus of teaching. Later views of listening drew on the field of cognitive psychology, which introduced the notions of bottom-up and top-down processing and brought attention to the role of prior knowledge and schema in comprehension. Listening came to be seen as an interpretive process. Hence, current views of listening emphasize the role of the listener, who is seen as an active participant in listening, employing strategies to facilitate, monitor, and evaluate his/her listening. It could be clearly seen that generally speaking, the findings of the study are consistent with the findings in the literature in that in the current study, it was revealed that listening comprehension is more effective when listeners are more active during the process of listening comprehension.

\section{Limitations of the Study}

Since conducting research is time-consuming and costly, the researchers encountered some limitations in the conduct of the study. They are provided here list-wise. First of all, given that the treatment was going to last a while and it was not feasible to select the participants from several areas or several cities, the findings of the study should be interpreted with caution. The second limitation was that the researchers could not spend more than 12 sessions with students. Longer periods of treatment may bring about different results. The third limitation has to do with the nature of the instruments used in the study. Given that listening comprehension usually poses a challenge to language learners, it was not possible to administer tests other than those contained in the textbook with which they usually dealt.

In the current study, the two approaches to listening comprehension were investigated. It is possible for other researchers to try the same approaches to teaching other language skills such as reading. Moreover, in the present study, only intermediate level of proficiency was targeted. It is possible to replicate the study with other proficiency levels. In addition, other variables such as gender and various age could be considered to see whether they make a difference or not.

\section{Implications of the Findings}

EFL learners, English teachers, syllabus designers, and methodologists can benefit from the findings of this study to improve listening comprehension. EFL learners can be self-directed in acquiring a new language and they can discover new ways for learning. English teachers can participate learners in learning procedure; they can provide studentcentered situations in listening classes. In the process-oriented approach, teachers are facilitators rather than instruction providers. Process-oriented approaches provide an opportunity for teachers to become aware of learners' progress in listening. They can also recognize students' troubles in listening domain and they can remove learners' problematic areas step by step in process-centered approach classes (Ten Cate et al., 2004).

Syllabus designers and methodologists can also benefit from the findings of this study. They can change instructions in terms of paying attention to the process of learning not considering the learning result. They can create some pretasks and post-tasks for engaging learners in listening skill and thus improve their listening comprehension and can give students considerable freedom within a task.

Given the indispensable role of input in language learning, listening and reading skills can serve as important sources of language input. Regarding the problems of language learners and teachers in EFL settings, the findings of this study can make classroom listening activities more productive. If teachers ponder listening as a process and not a product, they can provide situations in language classes in which students can make better jobs of listening. This is because the process-oriented approach of listening constructs an opportunity for the students to take part in listening activities by negotiation, discussion, and interaction.

In these classes, the emphasis is not only on the correct answers for the listening comprehension but also the students should apply some strategies for their listening comprehension which can inform EFL learners about their abilities. If process-oriented classes are more fruitful, language teachers and learners can choose to spend more time on listening as process. One of the most important implications of this research is to offer new ways in listening teaching which 


\section{International Journal of Research in English Education}

are currently ignored by most teachers; it allows both teachers and learners to be familiar with another side of listening skill.

Most studies in the field of teaching listening have examined the product-oriented approach in their classes. However, the insufficiency of this approach in listening needs to compare this approach with process-oriented one to see whether this new practice can result in more successful outcomes or not. In addition, learning is not limited to acquiring some knowledge or skill in product-centered approach. It is more about learning how to learn process-center approach (Van Duzer, 1997).

EFL learners, English teachers, syllabus designers, and methodologists can benefit from the findings of this study to improve listening comprehension practices. The reason is that listening comprehension has always been a challenge for L2 learners, especially when learning takes place in an EFL context. It is possible to draw on the findings to make informed decisions when it comes to teaching listening. Language teachers also could equally benefit from the findings of the study. This is especially important, as language teachers are usually clear about how to teach other language skills, but not so much clear about teaching listening comprehension. Moreover, in the light of the findings of the study, curriculum developers and methodologists can decide about the way in which listening comprehension must be taught in textbooks intended for listening comprehension. Teaching listening as a process or as a product has important implications for the way in which materials are developed and taught.

\section{References}

Chamot, A. U. (2004). Issues in language learning strategy research and teaching. Electronic journal of foreign language teaching, 1(1), 14-26.

Farrokhi, F., \& Modarres, V. (2012). The effects of two pre-task activities on improvement of Iranian EFL learners' listening comprehension. Theory and Practice in Language Studies, 2(1), 144-150. doi: 10.4304/tpls.2.1.144150

Feyten, C. M. (1991). The power of listening ability: An overlooked dimension in language acquisition. The modern language journal, 75(2), 173-180. doi: 10.1111/j.1540-4781.1991.tb05348.x

Goh, C. C. (2000). A cognitive perspective on language learners' listening comprehension problems. System, 28(1), 55-75. https://doi.org/10.1016/S0346-251X(99)00060-3

Hoven, D. (1999). A model for listening and viewing comprehension in multimedia environments. Language Learning \& Technology, 3(1), 88-103. Retrieved September 2, 2017 from https://www.learntechlib.org/p/90919/.

$\mathrm{Hu}$, G. (2002). Potential cultural resistance to pedagogical imports: The case of communicative language teaching in China. Language Culture and Curriculum, 15(2), 93-105. http://dx.doi.org/10.1080/07908310208666636

Kothari, C. R. (2004). Research methodology: Methods and techniques. New Delhi: New Age International (P) Ltd., (C)2004. (OCoLC) 62197369

Lynch, T. (2012). Promoting EAP learner autonomy in a second language university context. Research perspectives on English for academic purposes. Cambridge: Cambridge University Press. 390-403. doi: https://doi.org/10.1017/CBO9781139524766.029

Nunan, D. (1995). Closing the gap between learning and instruction. TESOL Quarterly, 29(1), 133-158. doi: $10.2307 / 3587808$

Onaka, F. (2013). Aspects of process theories and process-oriented methodologies in historical and comparative sociology: an introduction. Historical Social Research, 38(2), 161-171. URL: http://nbnresolving.de/urn:nbn:de:0168-ssoar-387845

Pourhosein Gilakjani, A. P., \& Ahmadi, M. R. (2011). A study of factors affecting EFL learners' English listening comprehension and the strategies for improvement. Journal of Language Teaching \& Research, 2(5), 977-988. doi:10.4304/jltr.2.5.977-988

Richards, J. C. (2003). Developing tactics for listening. Oxford: Oxford University Press.

Rubin, J. (1994). A review of second language listening comprehension research. The Modern Language Journal, 78(2), 199-221. doi: 10.1111/j.1540-4781.1994.tb02034.x 


\section{International Journal of Research in English Education}

Scanlon, E. (2005). The literacy experiences of ninth-graders and their teacher in an English language arts workshop. Ph.D. Dissertation, Department of Curriculum and Instruction, College of Education, University of Central Florida, Orlando, Florida. U.S.A.

Yaghoubi, S. T., \& Seyyedi, F. (2017). Listening strategies used by Iranian EFL learners in listening comprehension of TOEFL academic lectures: focus on gender. Modern Journal of Language Teaching Methods, 7(4), 327340.

Ten Cate, O., Snell, L., Mann, K., \& Vermunt, J. (2004). Orienting teaching toward the learning process. Academic Medicine, 79(3), 219-228.

Van Duzer, C. H. (1997). Improving ESL learners' listening skills: At the workplace and beyond. National Clearinghouse for ESL Literacy Education, Project in Adult Immigrant Education. 